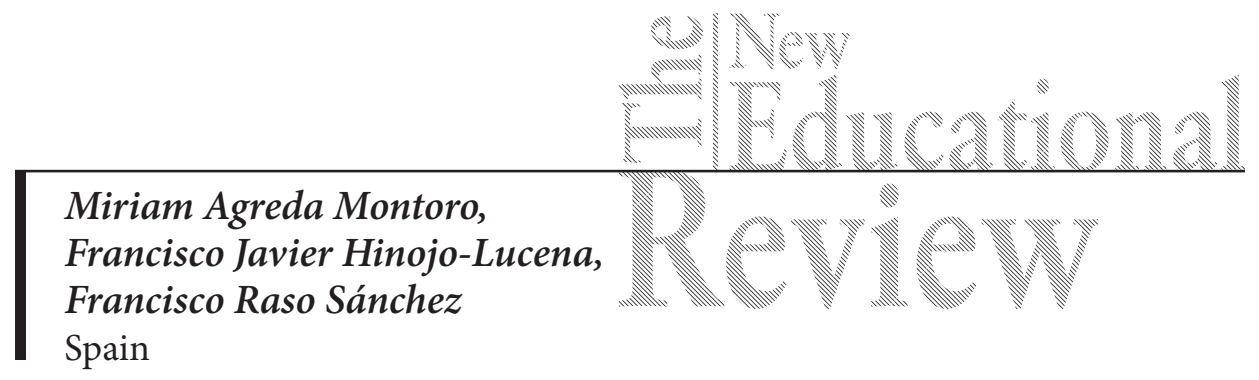

\title{
A Study on ICT Training among Faculty Members of Spanish Faculties of Education
}

DOI: $10.15804 /$ tner.2015.42.4.02

\begin{abstract}
Acquisition of digital skills by faculty members is a significantly important step when it comes to integrating ICT in teaching. In light of that, this study aims to describe and analyse faculty members' training in ICT in all faculties of education within Spanish public universities. The paper hereby presented describes results from 1,145 professors, obtained by an ad hoc online questionnaire. Both data and results have been obtained from one of the instrument dimensions: received teaching training and professors' perception of their own training. This instrument consists of 25 items. Results show the need for more profound training regarding the optimisation of ICT didactic and pedagogic potential in class, as well as an integrated approach to pedagogy, digital literacy and knowledge.
\end{abstract}

Keywords: ICT, faculty members, training, higher education, digital skills, technology enhanced learning

\section{Introduction}

Technology is evolving so fast that faculty members not only need to master contemporary ICT tools, but also to keep a comprehensive approach in order to face the implied continuum this evolution results in. Given this situation, professors face the challenge of being ready and trained to implement new learning environments, and also the need for mastering ICT in their professional life. Thus, faculty members play a new role, in which they become the origin of these new situations within the new learning environments where the teaching/learning 
process takes place: they are their students' mediators, tutors and guides, all at the same time (Cabero \& Román, 2006; Sanz \& Zangara, 2013).

Professors face a serious amount of pressure because of the need to update and renew their pedagogy towards ICT. This situation may result in a confidence loss and can also be the origin of their refusal to implement ICT in their teaching practices. This refusal can be explained by their inability to decipher the pedagogic potential of technology when it comes to helping their students to achieve a specific goal, so they decide to keep the traditional approach to the professor's role.

Shaltry et al. (2013) define six different stages of the decrease in faculty members' scepticism towards the use of new technologies in class. Although these stages are set within an online learning environment, we think they could help to bridge the gap between technology and teaching professionals. A cycle of six stages is then established: (1) awareness of online learning, (2) rejection of online learning, (3) understanding of all the possibilities online learning offers, (4) online learning practice, (5) sharing online learning resources and activities, and (6) being in favour of online learning.

We can conclude that faculty members must be aware of the importance of their digital skills: they must understand all the new possibilities ICT offer, use apps that may be useful for them when meeting the objectives of their curriculum planning, be aware of the importance of those objectives, and the importance of sharing their experiences in class to recommend the most useful resources. But this is not a one-size-fits-all and not everything works in every situation, although this is a very common approach, which leads teaching professionals to use every single new app. This may be one of the problems faculty members have to solve: new technologies are not a panacea for education and they cannot possibly give a solution to every single problem that teachers may encounter in class or in teacher training. We need to establish a difference between quality and quality in the pedagogical ICT use.

Cabero (2014) argues that faculty members must receive conceptual training in ICT within the educational context: they need to learn how ICT transforms and supports the learning environment. This may help to change the view we have about ICT and will help faculty members to update their work as well as to elaborate their own contents and educational resources. This will result in a change of their role of repeating other people's experiences and techniques.

According to Méndez (2012), "education professionals must update their methodology constantly. Teachers need to master ICT in a pedagogic way: they will always play a major role in the learning process as well as in the teaching of ethical and moral behaviours. They are in charge of modelling collective intelligences, 
encouraging future citizens to take more responsibility for themselves and society in general" (p. 21)

If we take into consideration the challenges faculty members in the Spanish faculties of education face, we can see that universities may have a lack of integration, efficiency, quality, flexibility and, last but not least, transformation and innovation of the educational experiences. All of that happens as a result of the gap between what is taught in class and what is required on the labour market nowadays. Students receive training that does not provide them, or teachers, with the appropriate tools and skills to develop their professional activities in the modern world. On top of that, curricula lack flexibility, they are too traditional and become out of date in this globalized world of ours.

This need for initial and constant training for professors has paved the way for institutions, both public and private, which offer a wide range of courses on education and ICT. Most of these are held online or with a semi-attendance format, in order to encourage this so-called pedagogical recycling (Cobo \& Moravec, 2011; Schmidt, Geith, Håklev, \& Thierstein, 2009; Stoyanov, Sloep, De Bie, \& Hermans, 2014).

The teaching profession and teacher training are vital and they gain even more importance because these concepts are evolving. Marcelo, Mayor \& Yot state that "[the teaching profession] is becoming a knowledge profession, not only because knowledge may have been or may be the core of the profession itself, but also because teaching professionals design learning environments and have the ability to make better use of the spaces where knowledge occurs" (2011:2)

A study on the level of digital skills among the newly graduates in infant education conducted by the University of Alicante shows very interesting results. The skills were divided into four groups: technological literacy, intellectual work instruments, information processing and dissemination, and communication tools.

The highest ranked item in the study is one in which "[the subject] shows an interest in updating his/her knowledge about ICT". Nevertheless, subjects admitted they had a higher level when they worked by themselves rather than in groups, contrary to what is expected by EHEA guidelines. This item is followed in the ranking by searching skills, localisation skills, and information evaluation and recovery skills.

"Website analysis and evaluation" was considered as a less important skill. This result allows for a conclusion that this may be so because the link students establish with websites is not seen as important enough (Roig \& Pascual, 2012).

One of the most important studies on ICT skills among faculty members was conducted by Prendes (2010). Its objectives were to create a selection of ICT skill 
indicators and afterwards work on a curriculum focused on the acquisition of those specific skills and their improvement.

A remarkable step ahead has been made by Rovira i Virgili University through the development of a digital skill self-assessment tool (INCOTIC). This tool is addressed to first-year students and its main goal is to change both the curriculum and the teaching methods to meet the students' needs. It also aims to pick on good methods and detect what is working and why. This tool helps professors to design individual training plans, which is the starting point of a monitoring process, and it also offers the possibility of providing a final assessment to develop an appropriate and high-quality training process (Gisbert, Espuny \& González, 2011)

After having discussed all of the above, some questions arise concerning the ICT training faculty members are provided with. We need to answer these questions in order to suggest ideas to improve this training and support the updating process: What kind of ICT training do professors have? Which training options do they use? Does this training provide professors with the skills needed for their professional activity? What improvements does this kind of training need? Do we provide our professors with good-quality training which results in gaining digital skills?

In light of these questions, we designed our research work, which aimed to describe and analyse ICT training among faculty members of Spanish faculties of education.

\section{$\underline{\text { Research Methodology }}$}

After having revised the literature on the topic and posed our research question, we decided to use a descriptive methodology, due to our intention of describing some aspects of educational reality. Our research design was based on a non-experimental research frame. This is the main reason why we used a survey as a research tool. More specifically, we used a questionnaire in order to collect data. The mentioned questionnaire had been designed ad hoc after an in-depth literature revision.

Population consisted of the whole of the faculty members who taught at Spanish faculties of education during the 2013/2014 academic year. Given this characteristic of our target population, we covered almost $100 \%$ of the working professors, so there was no need to sample or to determine the representativeness of the sample with the use of stratified random sampling, cluster sampling, random sampling, etc. 
For our study, we took into account the following sociodemographic variables: gender, department and university, professional status, and teaching experience. The questionnaire contains four dimensions and 118 items. We analysed and collected all data to reach our conclusions from the data obtained from dimension three, which deals with ICT training among faculty members. Dimension three consists of 26 items, classified using a four-point Likert rating scale -from none/ non-existent to very high.

\section{Research Results}

We worked with a finite population: 8,013 professors. We obtained a data-producing sample of 1,145 . The dimension reliability indexes are as follows (Tables $1 \& 2)$ :

Table 1. Reliability indexes. Cronbach's Alpha

\begin{tabular}{cc}
\hline $\begin{array}{c}\text { Cronbach's } \\
\text { Alpha }\end{array}$ & $\begin{array}{c}\text { N of } \\
\text { elements }\end{array}$ \\
\hline .964 & 26 \\
\hline
\end{tabular}

Table 2. Reliability indexes

\begin{tabular}{llll}
\hline Cronbach's Alpha & \multirow{2}{*}{ Part 1 } & Value & .929 \\
\cline { 2 - 3 } & & N of elements & $13^{\mathrm{a}}$ \\
\cline { 2 - 3 } & Part 2 & Value & .941 \\
\cline { 2 - 3 } & & N of elements & $13^{\mathrm{b}}$ \\
\cline { 2 - 3 } & \multicolumn{2}{l}{ Total N of elements } & 26 \\
\hline Correlation between forms & \multicolumn{2}{c}{ Equal length } & .977 \\
\hline Spearman-Brown coefficient & Unequal length & .934 \\
\cline { 2 - 3 } & & .933 \\
\hline Guttman's coefficient in two halves &
\end{tabular}

We grouped the variables which would indicate received training, both formal and informal. The summary is presented in Table 3. 
Table 3. Summary of received ICT training

\begin{tabular}{|c|c|c|c|c|c|c|c|c|}
\hline \multicolumn{9}{|c|}{ Received ICT training } \\
\hline & \multicolumn{2}{|c|}{ NONE } & \multicolumn{2}{|c|}{ LOW } & \multicolumn{2}{|c|}{ HIGH } & \multicolumn{2}{|c|}{ VERY HIGH } \\
\hline & Freq. & $\%$ & Freq. & $\%$ & Freq. & $\%$ & Freq. & $\%$ \\
\hline $\begin{array}{l}\text { Self-taught knowledge and } \\
\text { experimenting with ICT }\end{array}$ & 31 & $2.7 \%$ & 205 & $17.9 \%$ & 491 & $42.9 \%$ & 418 & $36.5 \%$ \\
\hline $\begin{array}{l}\text { Received ICT training } \\
\text { through either b-learning or } \\
\text { e-learning }\end{array}$ & 408 & $35.6 \%$ & 355 & $31.0 \%$ & 265 & $23.1 \%$ & 117 & $10.2 \%$ \\
\hline $\begin{array}{l}\text { Lifelong learning and up- } \\
\text { dating of digital skills due to } \\
\text { the evolution of educational } \\
\text { technology }\end{array}$ & 170 & $14.8 \%$ & 362 & $31.6 \%$ & 422 & $36.9 \%$ & 191 & $16.7 \%$ \\
\hline $\begin{array}{l}\text { Received training in the use } \\
\text { of mobile devices as peda- } \\
\text { gogical resources }\end{array}$ & 578 & $50.5 \%$ & 357 & $31.2 \%$ & 159 & $13.9 \%$ & 51 & $4.5 \%$ \\
\hline $\begin{array}{l}\text { Training in research software } \\
\text { and data processing \& data } \\
\text { collecting software }\end{array}$ & 296 & $25.9 \%$ & 378 & $33.0 \%$ & 326 & $28.5 \%$ & 145 & $12.7 \%$ \\
\hline $\begin{array}{l}\text { Professors' knowledge } \\
\text { updating and self-regulation } \\
\text { processes when dealing } \\
\text { with ICT changes within the } \\
\text { learning environment }\end{array}$ & 204 & $17.8 \%$ & 364 & $31.8 \%$ & 420 & $36.7 \%$ & 157 & $13.7 \%$ \\
\hline
\end{tabular}

It is clearly visible how the professors admitted being self-taught or preferring self-conducted experimentation when working with ICT resources: $-36.5 \%$ of the subjects, which increases to $79.4 \%$ if we count the "high level" as a whole.

A closer look at these results allows for concluding that technology evolves so fast that it becomes disruptive. That is the reason why teaching professionals have to learn how to use these tools following both a trial-and-error method and self-teaching.

Another conclusion that can be drawn from this table is that ICT is part of our daily life and, especially within the educational context, most teaching professionals show an interest in improving their digital skills. This leads them to self-teaching in order to improve and update their mastering of ICT resources.

However, the variables regarding the professors' knowledge updating and self-regulation processes dealing with ICT changes within the learning environment, as well as those analysing lifelong learning and updating of digital skills due 
to the evolution of educational technology, show how the results change between the low and high levels of the spectrum. Taking the first above-mentioned item, there are $36.7 \%$ of the professors at the high level, whereas there are $31.8 \%$ at the low level. The second item shows very similar results: $31.6 \%$ (low level) versus $36.9 \%$ (high level). "None" and "very high" levels do not show results above $10 \%$ or $15 \%$, respectively.

It could be argued that one of the causes of these results is that technology is evolving very fast, which results in new educational resources, so teaching professionals find it really difficult to keep updated and find quality use of ICT. By the time one has more or less learnt to use a resource, there is a new one which changes again our educational reality.

$33 \%$ of the teaching professionals have attended ICT courses in official educational institutions, whilst only $23.1 \%$ have followed online or semi-attendance programs. $70 \%$ of the professors have not received any, or almost any, training, either through online or semi-attendance programs.

Almost $70 \%$ of the interviewees said they had not been trained in research software or data processing and data collecting software in order to improve their research work. The results obtained concerning experimenting and self-teaching on how to use ICT tools allow for concluding that the use of most of the technological resources that aid university professors' professional activity is learnt by self-teaching, instead of through an official training program.

Mobile learning has become more and more important thanks to the development of the so-called "smart devices". Nevertheless, our results show that faculty members do not receive any training in the use of mobile devices as a pedagogical resource. As shown in Graph 1, the total of both the "low" (bajo) and "none" (nulo) levels is $81.7 \%$ of the interviewees.

The interviewees have a high perception of their abilities to solve problems through the use of ICT resources. The percentage of the professors who show a low perception of their problem-solving abilities using ICT is very low, namely $6.9 \%$. $41 \%$ of the professionals argue that their abilities are of a "very high" level. This total increases to $62 \%$ with both "high" and "very high" levels. There are however 349 professors (30.5\%) at the "low" level.

Most professors consider their mastery of ICT as a pedagogical resource as high (42.4\%) and very high (23.9\%). 33.7\% describe it as non-existent or low. This is a considerable result given that ICT resources have become increasingly important since the arrival of the Internet and the beginning of the so-called digital era.

ICT is characterised by the vision we all have about it: we think it is to be used during our free time, especially after the introduction of social networking. The 
Graphic 1. Training in m-learning and research

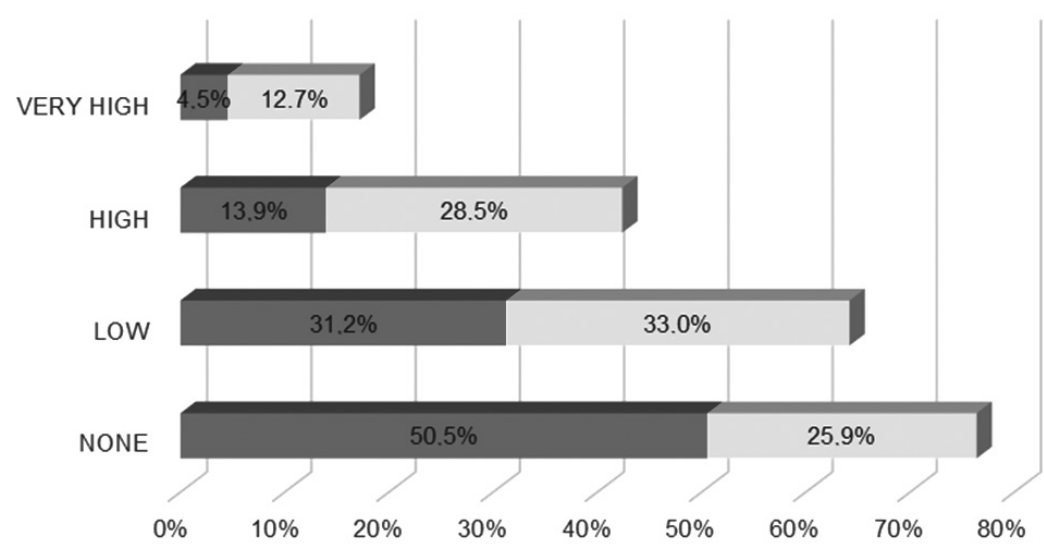

- Received training in the use of mobile devices as an educational resource

$=$ Training software dedicated to research and treatment and data collection.

capability of distinguishing their use differing depending on the situation is a vital skill, so trainers of future teaching professionals are able to make the best out of ICT in class. Results show a high level of the acquisition of this skill (43.2\% of the interviewees).

We would like to highlight here that the vast majority of the interviewees defined their ability to create and work with a contact network either as low (34.1\%) or non-existent (31.4\%). This may be related to similar results obtained when asking about online collaborative tasks.

Table 4 shows that the faculty members did not assess using any ICT tools. Most of the interviewees defined themselves as part of the low level (34.2\%), followed by the ones whose answer was "non-existent" (27.7\%)

Table 4. Professional assessment through ICT tools

\begin{tabular}{llccc}
\hline \multicolumn{1}{c}{$\begin{array}{c}\text { Professional } \\
\text { assessment through ICT } \\
\text { tools }\end{array}$} & Frequency & Percentage & $\begin{array}{c}\text { Cumulated } \\
\text { percentage }\end{array}$ \\
\hline Valid & NON-EX. & 317 & 27.7 & 27.7 \\
\cline { 2 - 5 } & LOW & 392 & 34.2 & 61.9 \\
\cline { 2 - 5 } & HIGH & 306 & 26.7 & 88.6 \\
\cline { 2 - 5 } & VERY HIGH & 130 & 11.4 & 100.0 \\
\cline { 2 - 5 } & Total & 1145 & 100.0 & \\
\hline
\end{tabular}


When considering the ability to classify information tools and information management software, most teaching professionals thought they had not acquired this skill: $35.5 \%$ (low level) and 21.4\% (non-existent). On the other side of the spectrum there are $32.2 \%$ of the interviewees who thought the opposite and defined this skill of theirs as a very high level one.

One of the most important, and most required, skills both for the labour market and in educational environments is being able to solve learning problems and being able to work within increasingly diverse contexts. The topic being discussed concerns facing these situations using technological support. Results show that $61.4 \%$ of the interviewees did not have this skill (non-existent) or their level of it was insufficient (low). However, the two higher levels of the table (38.6\% in total) indicate that this tendency is being reversed and that university professors are acquiring this skill.

Using cloud computing to create an interactive learning environment is a very widespread skill among the first three levels of our scale: low level of acquisition (31.9\%), high level (30\%). Very high level of acquisition is only declared by $16 \%$ of the interviewees.

Cloud computing offers a wide range of possibilities, such as working in different environments within it, both at individual and collaborative levels. This item shows the following results: $32.1 \%$ of the interviewees declared having a low level of the acquisition of this skill, $29.8 \%$ of the interviewees defined their level as high, and $26.4 \%$ said this skill was non-existent among them.

The results concerning their mastery of ICT use to carry out management and organisation tasks in research show that most subjects (59\%) defined the level of acquisition of this skill as high (level 3 of the scale).

Personal Learning Environments' (PLE) educational value has increased over the last few years. Although our results show that PLE creation and maintenance is not yet a strong point of the professors in the Spanish faculties of education ( $27 \%$ non-existent, $32.1 \%$ low), there is a paradigm shift proved by $40 \%$ of the interviewees who confirmed having acquired this skill at a high or a very high level. The following table (Table 5) shows a summary of items related to curriculum policy, ICT integration and faculty members' participation:

Table 5. Participation, knowledge and integration of education policy and ICT

\begin{tabular}{lllllllll}
\hline & \multicolumn{2}{c}{ NONE } & \multicolumn{2}{c}{ LOW } & \multicolumn{2}{c}{ HIGH } & \multicolumn{2}{c}{ VERY HIGH } \\
\cline { 2 - 8 } & Freq. & $\%$ & Freq. & $\%$ & Freq. & $\%$ & Freq. & $\%$ \\
\hline $\begin{array}{l}\text { Knowledge of ICT good } \\
\text { practice }\end{array}$ & 222 & $19.4 \%$ & 376 & $32.8 \%$ & 365 & $31.9 \%$ & 182 & $15.9 \%$ \\
\hline
\end{tabular}




\begin{tabular}{|c|c|c|c|c|c|c|c|c|}
\hline & \multicolumn{2}{|c|}{ NONE } & \multicolumn{2}{|c|}{ LOW } & \multicolumn{2}{|c|}{ HIGH } & \multicolumn{2}{|c|}{ VERY HIGH } \\
\hline & Freq. & $\%$ & Freq. & $\%$ & Freq. & $\%$ & Freq. & $\%$ \\
\hline $\begin{array}{l}\text { ICT integration in curriculum plan- } \\
\text { ning and its relation to teaching and } \\
\text { university curriculum policy }\end{array}$ & 187 & $16.3 \%$ & 415 & $36.2 \%$ & 357 & $31.2 \%$ & 186 & $16.2 \%$ \\
\hline $\begin{array}{l}\text { Participation in innovation projects } \\
\text { based on ICT use }\end{array}$ & 349 & $30.5 \%$ & 319 & $27.9 \%$ & 267 & $23.3 \%$ & 210 & $18.3 \%$ \\
\hline $\begin{array}{l}\text { Sharing ICT experiences in open } \\
\text { code }\end{array}$ & 587 & $51.3 \%$ & 299 & $26.1 \%$ & 175 & $15.3 \%$ & 84 & $7.3 \%$ \\
\hline $\begin{array}{l}\text { Comprehension and understanding } \\
\text { of digital skills national and interna- } \\
\text { tional standards and indicators }\end{array}$ & 448 & $39.1 \%$ & 362 & $31.6 \%$ & 242 & $21.1 \%$ & 93 & $8.1 \%$ \\
\hline $\begin{array}{l}\text { Knowledge of different reports about } \\
\text { the use of technology in education in } \\
\text { the short and medium term }\end{array}$ & 555 & $48.5 \%$ & 350 & $30.6 \%$ & 166 & $14.5 \%$ & 74 & $6.5 \%$ \\
\hline $\begin{array}{l}\text { Awareness of the importance of } \\
\text { digital skills in future teaching pro- } \\
\text { fessionals }\end{array}$ & 120 & $10.5 \%$ & 260 & $22.7 \%$ & 446 & $39.0 \%$ & 319 & $27.9 \%$ \\
\hline $\begin{array}{l}\text { The professor as a guide, a mediator } \\
\text { and an apprentice in the teaching/ } \\
\text { learning process: bilateral relation- } \\
\text { ship with students }\end{array}$ & 141 & $12.3 \%$ & 29 & $23.5 \%$ & 446 & $39.0 \%$ & 289 & $25.2 \%$ \\
\hline
\end{tabular}

Graph 2. Sharing of knowledge and experiences through ICT

$60 \%$

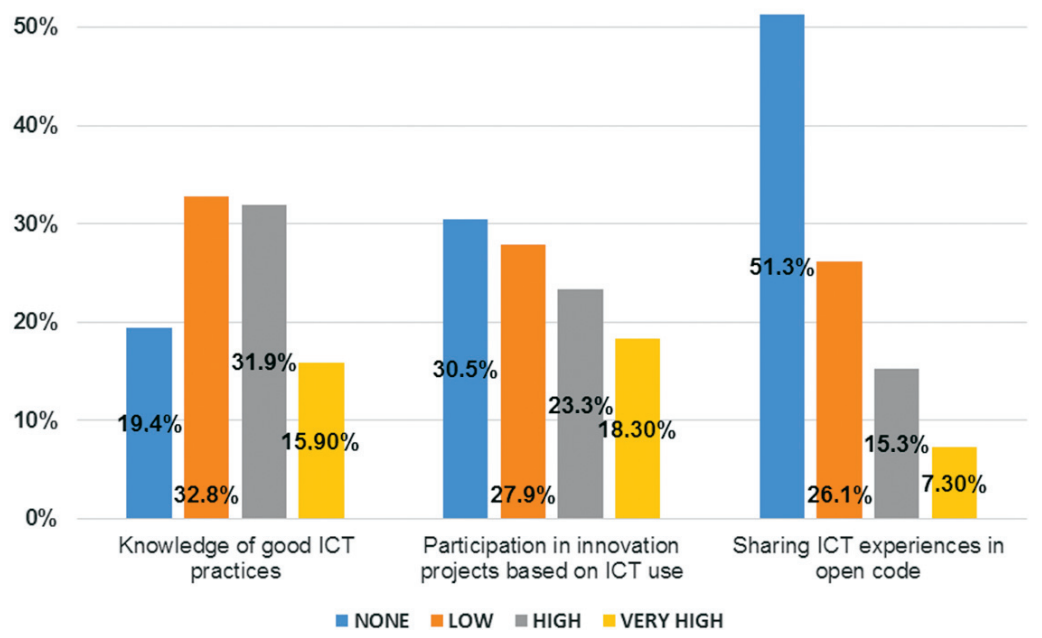


$67 \%$ of the faculty members are well aware of the importance of digital skills in future teaching professionals. On the other hand, 79.1\% have either non-existent or low notions about the different reports on the future of educational technology, such as the Horizon Report. The same concerns our fifth item: Comprehension and understanding of digital skills national and international standards and indicators, which shows a result of $39.1 \%$ for non-existent and $31.6 \%$ for low. It can be assumed that, in spite of the importance attached to future teaching professionals' digital skills, there is an important lack of information concerning the cutting-edge educational technology and its indicators.

Sharing experiences in open code gets an overall non-existent and low level. $15.3 \%$ of the interviewees chose a high level for this item, and only $7.3 \%$ chose "very high" as their answer. What is optimistic, however, is that $47.8 \%$ of the professors chose either a high or a very high level when it came to their knowledge of ICT good practice.

To conclude, we will analyse how the professors perceived the evolution of their teaching role after technology began to be used in education. The bar chart shows that the professor's role as mediator, guide and apprentice in the teaching/learning process, as well as the bidirectional relation with students, has been interiorized at a high and very high level (64.19\% of the interviewees). The professors stated that there was a change in how they perceived their role: they were not just mere purveyors of knowledge anymore, but a part in a bilateral relation where students and professors learnt from each other's feedback.

\section{Discussion}

Teacher training has acquired a new dimension in contemporary society: it has become vitally important. Lifelong learning has never been such an important need as it is today. As shown, both the labour market and the future of the teaching profession require technological literacy. This change of scenario must start with offering comprehensive and cross-disciplinary training to professors, in order to increase ICT quality use. Only then will ICT be able to create innovative education experiences that will have an actual impact on both teaching professionals and students.

Self-teaching and self-monitored experimentation with ICT tools is a major challenge among professors. This may be so because there are not enough training programs -or they do not solve professors' problems or meet their actual needs. Faculty members do not have the necessary tools to use ICT as pedagog- 
ical resources, or have the possibility of updating and improving the previously acquired knowledge.

When discussing this topic, the issue of research work cannot be forgotten. Faculty members do not use ICT as research tools, and this is a highly important field. As stated in the previous section, the evaluation of this item showed deficient results.

Although digital skills are seen as increasingly important, there is a lack of basic knowledge about new trends in educational technology and different national and international standards that assess this reality. As already shown, high-level results for this item are merely anecdotic.

Detecting the professors' ICT training needs must be the starting point for supporting the teaching work carried out in our faculties of education. This is vital because being trained on how to use ICT from the pedagogical point of view constitutes a key element for work with young pupils in nursery and primary schools.

We cannot forget that university has been the cradle of several innovative projects and experiences in education. University, as an institution, must work towards integration, efficacy, quality, flexibility, and must focus on transforming and updating educational experiences.

\section{References}

Adams Becker, S., Estrada, V., Freeman, A., \& Johnson, L. (2014). NMC Horizon Report: 2014 Higher Education Edition. Austin, Texas: New Media Consortium.

Cabero Almenara, J. (2014). Formación Del Profesorado Universitario En Tic. Aplicación Del Método Delphi Para La Selección De Los Contenidos Formativos. Educación XXI, 1(17), 109-132. doi:doi: 10.5944/educxx1.17.1.10707.

Cabero Almenara, J.C., \& Román-Graván, P. (Eds.). (2006). E-actividades: un referente básico para la formación en Internet. In E-actividades : un referente básico para la formación en Internet (pp. 23-32). Editorial MAD. Retrieved from http://dialnet.unirioja. es/servlet/libro?codigo $=10840$

Cobo, C., \& Moravec, J. (2011). Introducción al aprendizaje invisible: la (r) evolución fuera del aula. Reencuentro, (62), 66-81.

Crosetti, B. de B., Mesquida, A.D., Carrió, A.L., Juarros, V.M., García, J.M., \& Ibáñez, J.S. (2013). Agregación, filtrado y curación para la actualización docente. Pixel-Bit: Revista de Medios y Educación, (42), 157-169.

Gisbert Cervera, M., Espuny Vidal, C., \& González Martínez, J. (2011). INCOTIC. Una herramienta para la @utoevaluación diagnóstica de la competencia digital en la universidad. Retrieved from http://digibug.ugr.es/handle/10481/15327 
Hinojo Lucena, F.J., Aznar Díaz, I., \& Cáceres Reche, P. (2009). Percepciones del alumnado sobre el blended learningn en la universidad.

Hinojo Lucena, F.J. \& Martín, F.F. (2002). Diseño de escalas de actitudes para la formación del profesorado en Tecnologías. Comunicar, (19), 120-125.

Lisbôa, E.S., \& Coutinho, C.P. (2011). E-moderation in a thematic sample of orkut virtual communities: challenges and opportunities. Retrieved from http://repositorium.sdum. uminho.pt/handle/1822/12756

Martín, F.D.F., Hinojo Lucena, F.J., \& Aznar Díaz, I. (2002). Las actitudes de los docentes hacia la formación en tecnologías de la información y comunicación (tic) aplicadas a la educación.Contextos educativos, 5, 253-270.

Méndez, P.J. (2012). Mundos Cambiantes: La Tecnología y la Educación 3.0. Revista Complutense de Educación, 23(1), 11-22. doi:10.5209/rev_RCED.2012.v23.n1.39099

Prendes, M.P. (2010). Competencias TIC para la docencia en la Universidad Pública española. Indicadores y propuestas para la definición de buenas prácticas. Murcia: Universidad de Murcia. Retrieved from http.//www.um.es/ competenciastic

Raso-Sánchez, F., Cáceres Reche, P., \& Aznar Díaz, I. (2013). Teacher’s satisfaction concerning the use of ICT in rural educational Centers of Andalusia (Spain). The New Educational Review, 34(4), 246-257.

Roig, R., \& Pascual, A.M. (2012). Las competencias digitales de los futuros docentes. Un análisis con estudiantes de Magisterio de Educación Infantil de la Universidad de Alicante. @ Tic. Revista D’innovació Educativa, (9), 53-60. doi:10.7203/attic.9.1958

Sanz, C.V., \& Zangara, A. (2013). Las e-actividades como elemento central en el diseño de propuestas de educación mediada. In I Jornadas Nacionales de TIC e Innovación en el Aula. Retrieved from http://sedici.unlp.edu.ar/handle/10915/26547

Schmidt, J.P., Geith, C., Håklev, S., \& Thierstein, J. (2009). Peer-To-Peer Recognition of Learning in Open Education. The International Review of Research in Open and Distance Learning, 10(5). Retrieved from http://www.irrodl.org/index.php/irrodl/article/ view/641

Shaltry, C., Henriksen, D., Wu, M.L., \& Dickson, W.P. (2013). Situated learning with online portfolios, classroom websites and Facebook. TechTrends, 57(3), 20-25.

Stoyanov, S., Sloep, P., De Bie, M., \& Hermans, V. (2014). Teacher-training, ICT, creativity, MOOC, Moodle - What pedagogy? Retrieved from http://dspace.ou.nl/handle/ $1820 / 5463$ 